\title{
Criteria of Habitable Fishermen Settlements (Case Study of Fisherman Villages Sidoarjo)
}

\author{
Laili Maulidiyah, Dewi Septanti and Happy Ratna Santosa \\ Architecture Department, Institut Teknologi Sepuluh Nopember, Surabaya \\ e-mail: lailimldyh@gmail.com
}

\begin{abstract}
The slums that occur in fishpond settlements are not only based on environmental conditions, but also based on people's perceptions about the slum standards themselves. Physically, fishing houses in coastal areas are larger than substandard materials, dense, coincide, make dirty, look more easy, settlements, fishermen, can be categorized as slums. The situation of this slum-looking settlement is the result of a very high increase in the flow of urbanization with the aim of survival and life in a place that needs more resources that can be used to sustain life. The method used for this study with the criteria for assessing fishermen settlements in the case study. The results of this study consist of factors that cause slums and slum free village criteria based on the conditions of fishermen settlements in the case study living in coastal fishermen settlements. Get results from studies that can help and become one that can be used for livable and slum-free assistance on topics that exist in fishing villages in Indonesia.
\end{abstract}

Keywords-Fishermen Settlement, Slum Settlement, Habitable Settlement.

\section{INTRODUCTION}

$\mathrm{I}_{\mathrm{i}}^{\mathrm{n}}$ $\mathrm{N}$ fact in the coastal fishing village area in the case study in this study has the characteristics or uniqueness of the fishing community that is economic capital and social capital and also in the cultural aspects they have. Where the uniqueness of the economic activities of the majority of the residents of fishing village livelihoods by utilizing the potential of coastal areas rich in natural resources in the form of marine products and fishponds. The social life that is owned by the fishing village residents is also very unique because they have the majority of the same livelihood, so that the scope of their social activities tends to be the same in their daily activities. The culture that arises from the activities or activities of fishermen village residents who daily process fish products is a special attraction for residents from outside the fishing village. But it is unfortunate that the slums that exist in fishing villages into fishing villages are still lagging behind.

Consciously or not, residents of fishermen settlements respond to their homes by mobilizing all resources (physical, social, economic) to meet the needs of homes that are in accordance with the norm. There are businesses that can be done by residents of their homes, namely: Businesses to meet the needs when residents feel the lack of the house. The form of action can be in the form of changes or additions to the house. As happened in the homes of residents in fishing villages. That is because the occupants actively cause changes to the state of the house or are termed as housing adjustments [1].
Fishing settlements are a potential that is rich in abundant natural resources. It's just that there must be a movement for change to improve the current state of affairs. To awaken and direct the people who already have a culture of living in coastal areas like today.This is so that fishing village residents can improve their homes and improve the quality of the fishing settlement environment. This can also be an example and applied in coastal fishing villages throughout Indonesia.

\section{A. Research question}

This study improves the quality of settlements to evaluate the criteria of the coastal village of ponds to become slumfree and sustainable villages. Where a concept is needed that can be applied to the characteristics of the area and the inhabitants of a fishing village. Efforts to improve aspects of increasing slums in the coastal villages in Indonesia are expected to improve the quality of settlements by analyzing slum factors with economic improvement and community welfare. It is expected that the results of this analysis will receive suggestions that can be accepted by the community and can produce formulations of concepts that can be used in the improvement of the coastal villages of the pond so that they are free from slums and become a sustainable village.

In more detail, the research questions can be described as follows:

What are the factors that cause untidiness in fishing settlements based on slum criteria approved by Indonesia?

\section{B. Benefits of Research}

To identify the criteria of a coastal coastal village to be a slum free and sustainable village. Where the criteria themselves will be extracted from literary sources. Furthermore, the results of the criteria that are summarized will be analyzed consistently in this study in order to produce an appropriate and applicable concept formulation in realizing the coastal coastal village to be a sustainable village in accordance with the characteristics of the villagers. The hope, through this research can produce conceptual contributions that can be applied to solve the problems currently being faced in the conditions of coastal coastal settlement communities. However, it is not impossible the results of the study also have differences depending on the characteristics of each case study location. The benefits of the research can be reviewed from three aspects, namely the field of housing and settlement, government and society, as follows:

1. When viewed from the realm of housing and settlement science, this research has the benefit of knowing how much the role of theories learned in the field application. 
The $6^{\text {th }}$ International Seminar on Science and Technology (ISST) 2020

July $25^{\text {th }}$ 2020, Institut Teknologi Sepuluh Nopember, Surabaya, Indonesia

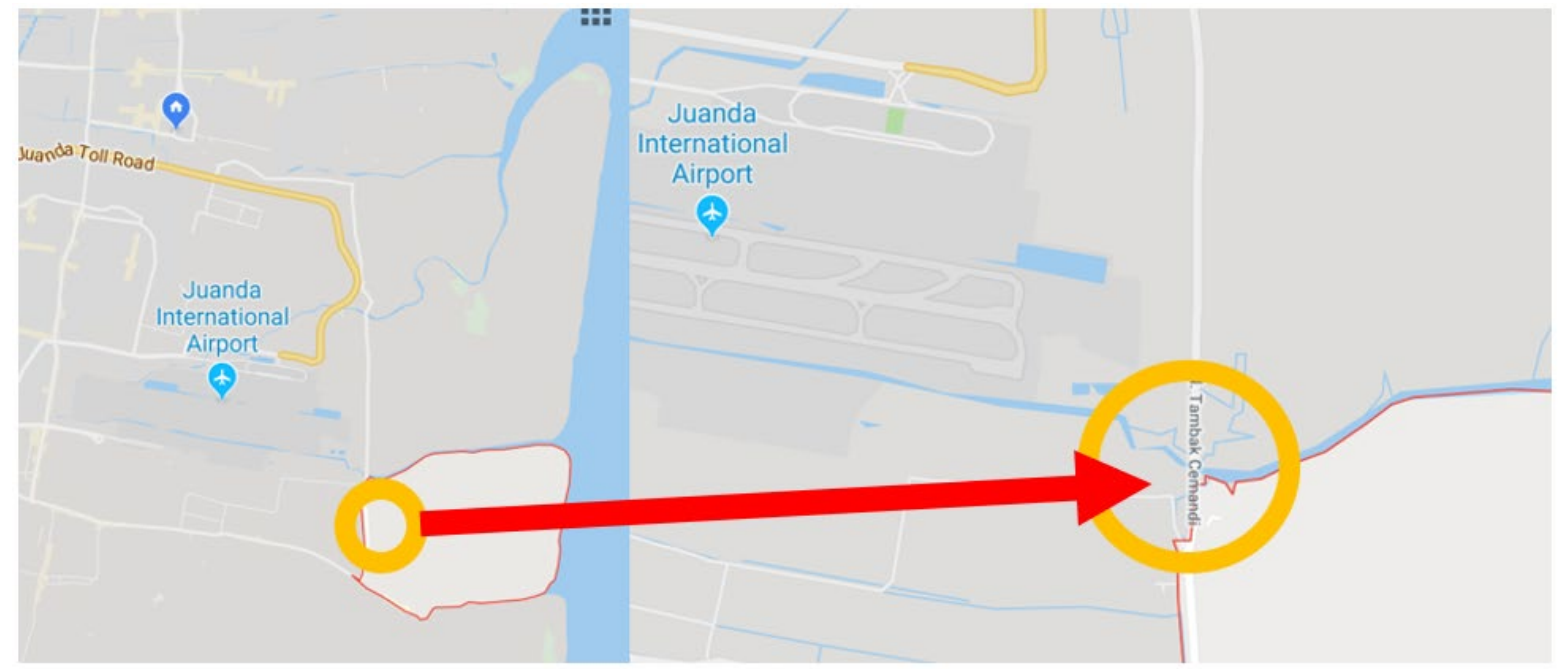

Figure 1. Research Sites
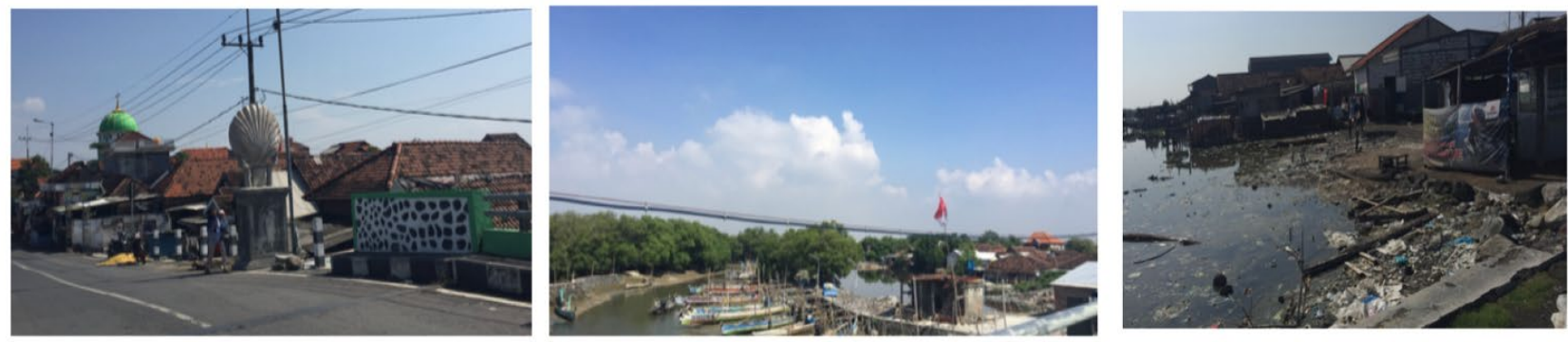

Figure 2. Existing Sites Conditions

Besides this research can be used as a reference literature relating to slums especially in coastal areas.

2. Benefits for the community is the results of this study can be used as motivation for the community to care about the importance of maintaining the residential environment. How to motivate the community is done by disclosing the existing environmental problems, reviewing people's expectations about improving settlements so as to create a sustainable environmental sustainability of settlements.

\section{Research Sites}

Based on the identification of the problem, the authors provide a scope of the scope of research to be conducted. Researchers only limit the problems in the fishing settlement area. In this study, researchers wanted to find out the factors that caused untidiness in fishermen's settlements, conducted evaluations, and produced a concept of fishing settlement areas that were integrated between literature studies, responses from local communities. The location that was made as a case study in this study consisted of three RTs and was located in Tambak Cemandi Village, Sedati District, Sidoarjo Regency, East Java, Indonesia can be seen in Figure 1.

The focus of the case study site boundaries in our study is the residential settlements located along the Tambak Cemandi Corridor as visualized from the detailed case study locations.

This village was chosen as a case study because of its strategic location, has boundaries with mangroves and the characteristics of the right area in this village there is a fish auction place from the residents in the village. This makes the fishing village in this case study widely known by people from other villages. But unfortunately this village is not yet organized and the conditions of the residents' settlements and environment are classified as slums.

\section{LITERATURE REVIEW}

\section{A. Slums}

The slum environment can be defined as follows: A densely populated environment (exceeding 500 people per hectare), socioeconomic conditions of the community is low, the number of houses is very dense and the size is below standard, the infrastructure is absent or does not meet technical requirements and health, Dwelling is built on land owned by the state or other people and outside the legislation in force[2]. Description of the slum environment are: Settlement environment where the conditions of residence or place of residence are crowded, The area of the house is not proportional to the number of inhabitants, The house is just a place to protect from heat and rain, Occupancy is temporary and is built on land not belonging to the occupants, the environment and the procedure irregular settlements without planning, lack of infrastructure (MCK, clean water, drainage, electricity, environmental roads), lack of social facilities (schools, houses of worship, medical centers), temporary livelihoods and non-formal businesses, low community education.

Meanwhile, because of the existence of slums are: Building characteristics: age of buildings that are too old, not organized, ventilation, lighting and sanitation that do not meet the requirements[3]. Environmental character: no open 
The $6^{\text {th }}$ International Seminar on Science and Technology (ISST) 2020

July $25^{\text {th }} 2020$, Institut Teknologi Sepuluh Nopember, Surabaya, Indonesia

Table 1.

Aspect and Parameter

\begin{tabular}{|c|c|c|c|}
\hline Aspect & Source & Operational definition & Indicator \\
\hline Occupant Density & $\begin{array}{l}\text { Khomarudin, } 1997 \\
\text { Sinulingga , } 2005\end{array}$ & A densely populated environment & $\begin{array}{l}\text { Exceeds } 500 \text { people per Ha , } 250-400 \text { inhabitants / } \\
\text { Ha }\end{array}$ \\
\hline Economic conditions & Khomarudin, 1997 & $\begin{array}{l}\text { Low socioeconomic condition of the } \\
\text { community }\end{array}$ & $\begin{array}{l}\text { The level of community income, the level of } \\
\text { community education }\end{array}$ \\
\hline Land Ownership & Khomarudin, 1997 & $\begin{array}{l}\text { Dwelling is built on land owned by the } \\
\text { state or other people and outside the } \\
\text { applicable law. }\end{array}$ & Private ownership of residential land \\
\hline Building Character & Nawagamuwa 2003 & $\begin{array}{l}\text { The age of the building is too old, not } \\
\text { organized, ventilation, lighting and } \\
\text { sanitation are not eligible }\end{array}$ & $\begin{array}{l}\text { The building is easy to move, } \\
\text { Built with makeshift materials, } \\
\text { Most are built by residents (slums from the start). }\end{array}$ \\
\hline $\begin{array}{l}\text { Environmental } \\
\text { Character and Public } \\
\text { Facilities }\end{array}$ & Nawagamuwa 2003 & $\begin{array}{l}\text { Availability of open space (green open } \\
\text { space) and public facilities }\end{array}$ & $\begin{array}{l}\text { Availability of open space and public facilities } \\
\text { within a radius of } 1 \mathrm{~km}\end{array}$ \\
\hline $\begin{array}{l}\text { Condition of the } \\
\text { building }\end{array}$ & $\begin{array}{l}\text { PU Cipta Karya } 2015 \text { - } \\
\text { SNI 03-1733-2004 }\end{array}$ & $\begin{array}{l}\text { Buildings that have safety standards, } \\
\text { building reliability, and meet building } \\
\text { criteria }\end{array}$ & $\begin{array}{l}\text { Structure and construction system } \\
\text { Building; and } \\
\text { Building material. }\end{array}$ \\
\hline Road Accessibility & $\begin{array}{l}\text { PU Cipta Karya } 2015 \text { - } \\
\text { SNI 03-1733-2004 }\end{array}$ & $\begin{array}{l}\text { Roads that have safety, security, smooth, } \\
\text { economic, comfort and environment } \\
\text { friendly standards }\end{array}$ & $\begin{array}{l} \pm 4 \mathrm{~m} \text { width that exists in residential units or } \\
\text { residential environments }\end{array}$ \\
\hline Drinking water service & $\begin{array}{l}\text { PU Cipta Karya } 2015 \\
\text { SNI 03-1733-2004 }\end{array}$ & $\begin{array}{l}\text { K4 Standards (Quantity, Quality, } \\
\text { Continuity, Affordability) }\end{array}$ & $\begin{array}{l}\text { City or neighborhood network availability up to the } \\
\text { house connection, } \\
\text { Pipes that are planted in the ground using PVC, } \\
\text { GIP or glass fiber pipes; and pipes installed above } \\
\text { the ground without protection using GIP. }\end{array}$ \\
\hline Drainage & $\begin{array}{l}\text { PU Cipta Karya } 2015 \text { - } \\
\text { SNI 03-1733-2004 }\end{array}$ & Reduced inundation & $\begin{array}{l}\text { There are culverts, confluence of channels, sluice } \\
\text { gates, pumps and downtown channels }\end{array}$ \\
\hline Wastewater & $\begin{array}{l}\text { PU Cipta Karya } 2015 \\
\text { SNI 03-1733-2004 }\end{array}$ & $\begin{array}{l}\text { AL that meets the quality standards, } \\
\text { affordability and lost contact with waste }\end{array}$ & $\begin{array}{l}\text { Septic tanks, infiltration fields and wastewater } \\
\text { pipelines. }\end{array}$ \\
\hline Waste management & PU Cipta Karya 2015 & $\begin{array}{l}\text { Waste Management that meets the } \\
\text { standards }\end{array}$ & There is 1 Waste Disposal Site in $1 \mathrm{RW}$ \\
\hline
\end{tabular}

space (green open space) and no facilities for family recreation; high population density; infrastructure that is not well planned.

According to them, the slums can reflect the economic, social and cultural conditions of the residents of the settlement. The characteristics of slums can be reflected in: Physical appearance of buildings that are poor in construction, that is, the number of temporary buildings that stand up and appear to be neglected or without maintenance, Low incomes reflect their economic status, usually lowincome slum communities, Building densities high, can be seen no distance between buildings and unplanned siteplan, high population density and heterogeneous society, poor or not in a good sanitation system, bad social conditions can be seen with a lot of criminal or criminal acts, The large number of migrants who reside by renting a house.

As a result, slums have emerged in several areas of the city which is unavoidable, that is not planned by the government but grows as a natural process. In a variety of literature can be seen various criteria in determining whether or not the slums of a residential area. According to a study conducted by the Postgraduate Program in Architecture Department, Sepuluh November Institute of Technology, Surabaya to determine the slums of an area, it can be viewed from four aspects, namely: the condition of buildings or houses, the availability of basic infrastructure and the environment, the vulnerability of population status, and based on supporting aspects, such as the lack of adequate employment, lack of community participation in social activities and it can be said that there are almost no facilities that are built together with non-government organizations and non-government organizations.

\section{B. Regulations Regarding Slums}

Regulation of the Minister of Public Works and Public Housing in "Regulation of The Minister of Public Work and Housing of The Republic of Indonesia Number 02 / PRT/ M / 2016" concerning the criteria for slums and slums [4]. Slums criteria in terms of:

a. Building;

b. Environmental road;

c. Provision of drinking water;

d. Environmental drainage;

e. Waste water management;

f. Waste management; and

g. Fire protection 
The $6^{\text {th }}$ International Seminar on Science and Technology (ISST) 2020

July $25^{\text {th }} 2020$, Institut Teknologi Sepuluh Nopember, Surabaya, Indonesia

Table 2.

Result and Conlusion of Research

\begin{tabular}{|c|c|c|c|}
\hline No. & $\begin{array}{l}\text { Aspect or } \\
\text { Factor }\end{array}$ & Identification Results & Causes of slum \\
\hline 1 & $\begin{array}{l}\text { Density of } \\
\text { Fisherman } \\
\text { Settlement } \\
\text { Residents }\end{array}$ & $\begin{array}{l}\text { Based on the above analysis shows that the condition of fishermen settlements in } \\
\text { cemandi ponds is relatively high around } 201-400 \text { people / ha. Because the population in } \\
\text { the study area amounted to } 227 \text { souls / ha. The density of } 16 \text { people / ha in this area is } \\
\text { not yet felt to be overcrowded. Although the condition of settlements in the coastal area } \\
\text { still looks tenuous but leads to conditions that are quite dense. So prevention is needed } \\
\text { to increase the number of new houses on the same land because it can result in high } \\
\text { density which is concentrated in the fishing settlement area. }\end{array}$ & $\begin{array}{l}\text { Yes, including the } \\
\text { factors causing the } \\
\text { untidiness of } \\
\text { fishermen } \\
\text { settlements. }\end{array}$ \\
\hline 2 & $\begin{array}{l}\text { Fisherman } \\
\text { Settlement } \\
\text { Land } \\
\text { Ownership }\end{array}$ & $\begin{array}{l}\text { The condition of community unrest that lives in fishing settlements on the pond is due } \\
\text { to residents who actually want to buy in installments by cooperatives but the authorities } \\
\text { do not want to release the land to the community. In the legal perspective, the Juanda } \\
\text { cooperative should comply with the rules in Article } 35 \text { paragraph } 1 \text { of the Loga on } \\
\text { Building Use Rights: the right to erect and own buildings on land that is not his own, } \\
\text { with a maximum term of } 30 \text { years. So it is necessary to hold negotiations on the } \\
\text { contract agreement from a lease of } 10 \text { years to } 30 \text { years in accordance with applicable } \\
\text { regulations, so that people feel more secure from evictions or changes at any time. }\end{array}$ & $\begin{array}{l}\text { Yes, including the } \\
\text { factors causing the } \\
\text { untidiness of } \\
\text { fishermen } \\
\text { settlements. }\end{array}$ \\
\hline 3 & $\begin{array}{l}\text { Character of } \\
\text { Fisherman } \\
\text { Settlement } \\
\text { Building }\end{array}$ & $\begin{array}{l}\text { Needed direction and understanding of the cause and effect caused by slums in their } \\
\text { village area. Give direction related to the improvement of the condition of their homes } \\
\text { so that they have a building that is comfortable, attractive and functional. Later it will } \\
\text { have an impact on the tourism or other sectors of the economy. }\end{array}$ & $\begin{array}{l}\text { Yes, including the } \\
\text { factors causing the } \\
\text { untidiness of } \\
\text { fishermen } \\
\text { settlements. }\end{array}$ \\
\hline 4 & $\begin{array}{l}\text { Character of } \\
\text { the } \\
\text { Environment } \\
\text { and Public } \\
\text { Facilities }\end{array}$ & $\begin{array}{l}\text { The need for direction and understanding of environmental quality and health hazards } \\
\text { in the settlements they live in are under slum conditions. So they need an understanding } \\
\text { of the causes and effects that arise due to poor environmental conditions in their village } \\
\text { area. Provide direction, as well as advice on policies related to violations committed if } \\
\text { there can be poor health and hygiene conditions in their own environment. }\end{array}$ & $\begin{array}{l}\text { Yes, including the } \\
\text { factors causing the } \\
\text { untidiness of } \\
\text { fishermen } \\
\text { settlements. }\end{array}$ \\
\hline 5 & $\begin{array}{l}\text { Building } \\
\text { Conditions in } \\
\text { Fishermen } \\
\text { Settlements }\end{array}$ & $\begin{array}{l}\text { The lack of understanding of the quality of the building they live in can have an impact } \\
\text { on their own health and have an impact on creating slums in their home environment. } \\
\text { So they need an understanding of the cause and effect that arises due to the condition of } \\
\text { their buildings that are not in accordance with the standards, as well as suggestions for } \\
\text { home design that conforms to standards so that it can have a good impact on the health } \\
\text { and hygiene conditions in their own environment. }\end{array}$ & $\begin{array}{l}\text { Yes, including the } \\
\text { factors causing the } \\
\text { untidiness of } \\
\text { fishermen } \\
\text { settlements. }\end{array}$ \\
\hline 9 & Wastewater & $\begin{array}{l}\text { The residential area in the case study does not have wastewater management. The } \\
\text { community has a low concern regarding proper waste management according to } \\
\text { standards. So they need an understanding of the cause and effect that arises due to these } \\
\text { conditions. It should be a matter of conveying the aspirations of the residents to the } \\
\text { landowners, or the local government to improve good waste management in fishermen } \\
\text { settlements. }\end{array}$ & $\begin{array}{l}\text { Yes, including the } \\
\text { factors causing the } \\
\text { untidiness of } \\
\text { fishermen } \\
\text { settlements. }\end{array}$ \\
\hline 10 & $\begin{array}{l}\text { Solid Waste } \\
\text { Management }\end{array}$ & $\begin{array}{l}\text { The settlement area in the case study does not have waste management. The community } \\
\text { has a very low concern regarding the correct processing of waste according to the } \\
\text { standard. So they need an understanding of the cause and effect that arises due to these } \\
\text { conditions. And there should be rules that are binding and take firm action so that local } \\
\text { communities are disputed according to existing standards and rules. }\end{array}$ & $\begin{array}{l}\text { Yes, including the } \\
\text { factors causing the } \\
\text { untidiness of } \\
\text { fishermen } \\
\text { settlements. }\end{array}$ \\
\hline 11 & Fire Safety & $\begin{array}{l}\text { The residential area in the case study does not have fire protection from the } \\
\text { government. Coupled with the community has a very low concern related to the correct } \\
\text { fire protection according to standards. So they need an understanding of the cause and } \\
\text { effect that arises due to these conditions. The government should pay more attention to } \\
\text { the conditions and availability of fire protection for its citizens. }\end{array}$ & $\begin{array}{l}\text { Yes, including the } \\
\text { factors causing the } \\
\text { untidiness of } \\
\text { fishermen } \\
\text { settlements. }\end{array}$ \\
\hline
\end{tabular}

The slum criteria in terms of buildings include:

1) Building irregularities as referred to in paragraph (1) letter a are the condition of buildings in housing and settlements:

a. Does not meet the building layout requirements in the Detailed Spatial Plan (RDTR) and the Building and
Environmental Planning Plan (RTBL), at least setting the shape, size, placement, and appearance of the building in a zone; and / or

b. Failure to comply with building and environmental quality regulations in the RTBL, at least the 
The $6^{\text {th }}$ International Seminar on Science and Technology (ISST) 2020

July $25^{\text {th }} 2020$, Institut Teknologi Sepuluh Nopember, Surabaya, Indonesia

arrangement of environmental blocks, lots, buildings, floor height and elevation, the concept of environmental identity, the concept of environmental orientation, and the face of the road.

2) A high level of building density that is not in accordance with the provisions of the spatial plan as referred to in

a. paragraph (1) letter $b$ shall constitute the condition of buildings in housing and settlements with:

b. Building Base Coefficient (KDB) that exceeds the provisions of the RDTR, and / or RTBL; and / or

c. Building Floor coefficient (KLB) that exceeds the provisions in the RDTR, and / or RTBL.

3) The quality of buildings that do not meet the requirements referred to in paragraph (1) letter $\mathrm{c}$ is the condition of buildings in housing and settlements that are not in accordance with technical requirements.

4) The technical requirements for building construction referred to in paragraph (4) consist of:

a. Control of environmental impacts;

b. Construction of buildings above and / or below ground, above and / or under water, above and / or under public infrastructure / facilities;

c. Safety of buildings;

d. Building health;

e. Comfort of buildings; and

f. Ease of building.

\section{METHODS}

The method can be interpreted as a process or way of achieving research objectives. Methodology is a process that has focused on the general research process throughout the range of architectural research [5]. Chapter three will explain the selection of research methods, starting with the research paradigm, research strategies and research techniques.

In this research activity, there is a paradigm used by researchers. This research uses the post-positivism paradigm. The post-positivism paradigm is a paradigm that is characterized by beliefs that are more diverse than external reality which can only be known at some level of possibility. There is still the possibility of external reality, that is, from outside the scope of the settlement environment, but is also biased on economic facts, and social facts on the settlement environment that exist in case studies and internal, namely the conditions of the slum that can affect.

This study uses the post-positivism paradigm because the researcher considers that the objectivity of this research is not a mechanistic law that is permanent but there are still external influences that can influence it. As for achieving the second research objective related to the development of village improvement programs, researchers conducted a literature study and in-depth interviews with several related sources. So there are still interpretations from sources who can influence research. Meanwhile, to achieve the third goal related to the community on the concept, researchers conducted observations, interviews and surveys by distributing questionnaires, so that the objectivity of the study was also affected by the researchers 'interpretation and the respondents' interpretations.
The research techniques used are adapted to the research methods conducted.

1. Research Techniques in Qualitative Methods

Research techniques used in qualitative research methods include:

a. Interactive, i.e. by knowing opinions or perceptions obtained from users or the public, through interviews and discussions

b. Identification, by codifying, reducing and verifying the data that has been obtained.

c. Observation, by observing the environment in the research area. Among them include:

- Observing community activities that occur at the study site.

- Observe adjustments or changes made by someone to the surrounding environment to support their activities.

- Observe and identify the environmental conditions of fishing community settlements.

d. Descriptive, by describing, documenting and analyzing it according to what you want to achieve in the research objectives.

e. Case Study Research Techniques, research techniques used in the case study research methods include:

1. Observation

2. Survey

3. Interview

4. Descriptive

5. Analysis of documents

6. Interpretation

7. Explanation

\section{GENERAL DESCRIPTION}

Conditions in the area which are the object of case studies in the study. Having environmental conditions that are classified as slums in the area around the fishing settlements in the Village Tambak Cemandi. The irregularity of buildings in this study area is because the houses in this area grow naturally. So it has irregular roads or corridors with very natural characteristics or grows spontaneously and naturally like informal settlements. Likely in Figure 2.

\section{RESULT AND DISCUSSION}

The result and conclusion of thi research can be seen in Table 2. The conclusion from the results of the final analysis in this study is to formulate the concept of developing slumfree fishing settlement areas with the concept of Sustainable Cities and Communities.

Factors that cause untidiness in fishing settlements are based on SNI slum criteria that exist in Indonesia. And has been analyzed based on the results of research in a case study in Tambak Cemandi Sidoarjo Fishing Village has the results of the research conclusions include several factors.

\section{REFERENCES}

[1] Morris, Desmond. 1977. A Fied Guide Human Behavior. New York: N.Abrams Inc. 
The $6^{\text {th }}$ International Seminar on Science and Technology (ISST) 2020

July $25^{\text {th }} 2020$, Institut Teknologi Sepuluh Nopember, Surabaya, Indonesia

[2] Khomarudinm. 1997, Menelusuri Pembangunan Perumahan dan Permukiman, Jakarta: Yayasan Real Estate Indonesia, PT. Rakasindo, Jakarta.

[3] Nawagamuwa, Arawinda. 2003. Slum, Squatter Areas and Informal Settlement, 9th. International Conference On Sri Lanka Studies, Matara, Sri Lanka, and Nils Viking.
[4] Regulation of The Minister of Public Work and Housing of The Republic of Indonesia Number 02 / PRT/ M / 2016.

[5] Groat L and Wang D, (2013), Architectural Research Methods Second Edition. Canada, USA : John Wiley and Sons Inc. 